\title{
A Pilot Study on Effect of Beta2-Adrenergic Receptor Gene Polymorphism on Response to Fluticasone/Formoterol Inhaler in Patients with Persistent Asthma
}

\author{
Motohiro Kurosawa ${ }^{1,2^{*}}$, Tatsuo Yukawa ${ }^{3}$ and Eijin Sutoh ${ }^{1}$ \\ ${ }^{1}$ Department of Allergy and Respiratory Medicine, Sutoh Hospital, Annaka-shi, Gunma, Japan \\ ${ }^{2}$ Gunma Institute for Allergy and Asthma, Gunma, Japan \\ 3Yukawa Clinic of Internal Medicine, Tochigi, Japan \\ *Corresponding author: Kurosawa M, Department of Allergy and Respiratory Medicine, Sutoh Hospital, 3532-5 Annaka, Annaka-shi, Gunma 379-0116, Japan, Tel: \\ +81-27-382-3131; Fax: +81-27-382-6568; E-mail: motohiro@kl.wind.ne.jp
}

Received date: February 25, 2015, Accepted date: April 01, 2015, Published date: April 07, 2015

Copyright: (c) 2015, Kurosawa M et al. This is an open-access article distributed under the terms of the Creative Commons Attribution License, which permits unrestricted use, distribution, and reproduction in any medium, provided the original author and source are credited.

\begin{abstract}
Background: Safety concerns have been raised regarding the regular use of long-acting B2-agonists (LABAs) with inhaled corticosteroids (ICSs), and some studies suggested patients with asthma who are homozygous for arginine (ArgArg) at the 16th amino acid position of the B2-adrenergic receptor (ADRB2) gene benefit less from treatment with ICS/LABA than do those homozygous for glycine (GlyGly). Phase III trial of fluticasone/formoterol, which consisted of 8-week, multicenter randomized single-blinded parallel-group study and 52-week, multicenter open-label study, have been conducted in Japan. In the trials, we performed a pilot study on effect of ADRB2 gene polymorphisms on lung function and asthma control to regular use of the new ICS/LABA inhaler.
\end{abstract}

Methods: As number of patients was limited to each institution, nine patients were allowed to participate in this pilot study. DNA in the specimens in patients with persistent asthma was extracted, and the target DNA sequence of the gene was amplified. Allelic discrimination assay for single nucleotide polymorphisms relating to the ADRB2 was carried out.

Results: In the 8-week study, patients with either ArgArg or ArgGly genotype showed good changes of peak expiratory flow (PEF) values from baseline with fluticasone/formoterol treatment. In the 52-week study, the improvement of lung function tests (forced expiratory volume in one second and PEF) from baseline was observed with the treatment, and all of the daily diary-based measures of asthma control were improved from baseline in each patient over the treatment period irrespective of their genotypes of ADRB2.

Conclusion: This is the first prospective pilot study, which might suggest inheritance of ADRB2 gene polymorphisms may not appear to effect clinical outcomes with fluticasone/formoterol inhaler.

Keywords: Beta2-adrenergic receptor; Gene polymorphism; ADRB2; Fluticasone; Formoterol; Combination therapy; Asthma

\section{Introduction}

Combination therapy with long-acting $\beta 2$-adrenergic agonists (LABAs) and inhaled corticosteroids (ICSs) has been one of the most widely prescribed treatments for the control of asthma in the world, and this combination therapy has been endorsed in the Global Initiative for Asthma (GINA) guidelines for the treatment of moderate to severe asthma in 2006 [1]. Based on safety concerns about LABAs raised by the Food and Drug Administration (FDA) in the United States in February 2010 [2], the FDA issued a requirement on April 14, 2011 for all manufactures of LABAs that are marked for asthma in the United States to conduct controlled clinical trials to assess the safety of regimen of ICS/LABA [3].

Recent pharmacogenetic studies demonstrated that the B2adrenergic receptor (ADRB2) gene polymorphisms modify bronchodilating response to regular use of albuterol [4,5]. With respect to LABA therapy, it has been reported that asthmatic patients with the homozygous for arginine (ArgArg) at codon 16 of the ADRB2 gene have an impaired therapeutic response to salmeterol in either the absence or presence of ICS [6,7]. Also, ethnic-specific pharmacogenetic difference in response to salmeterol has been suggested in individuals with different ADRB2 genotypes [8]. In contrast, other studies reported that ADRB2 gene polymorphisms did not result in significant change of bronchodilating response to LABAs in the presence of ICSs $[9,10]$. The results of some studies seemed to be limited by their retrospective design and inability to control for specific factors.

The ICS, fluticasone propionate (fluticasone), delivers a potent and sustained anti-inflammatory effect [11], and the LABA, formoterol has a fast onset of action and prolonged bronchodilatory effect [12]. The new ICS/LABA combination of fluticasone/formoterol has become available first in Germany and the United Kingdom in September 2012, with subsequent launches in other European countries for administration via a single pressurized metered-dose inhaler (pMDI).

Also in Japan, phase III trials of the ICS/LABA pMDI have been performed. The trials in Japan consisted of two studies, study I and study II $[13,14]$. Namely, study I was 8 -week, multicenter (88 centers in Japan) randomized single-blinded parallel-group study, and was composed of a 28-day screening, 2-week run-in (fluticasone $200 \mu \mathrm{g}$ daily), and 8 -week treatment periods. Patients aged $\geq 16$ years 
Citation: Motohiro Kurosawa, Tatsuo Yukawa and Eijin Sutoh (2015) A Pilot Study on Effect of Beta2-Adrenergic Receptor Gene Polymorphism on Response to Fluticasone/Formoterol Inhaler in Patients with Persistent Asthma. J Allergy Ther 6: 208. doi: $10.4172 / 2155-6121.1000208$

Page 2 of 6

( $\mathrm{N}=455)$ with persistent asthma for $\geq 6$ month before screening, FEV 1 $50-85 \%$ predicted, and $>12 \%$ and $>200 \mathrm{~mL}$ reversibility following albuterol inhalation were randomized to receive fluticasone/ formoterol $100 / 10 \mu \mathrm{g}$ twice daily $(\mathrm{N}=228)$ or fluticasone $100 \mu \mathrm{g}$ twice daily (N=227) for 8 weeks (Clinical Trials Gov JapicCTI number: 101340) [13]. Study II was a long-term (52 weeks), multicenter (71 centers in Japan) open-label study assessing the safety and efficacy of fluticasone/formoterol, and was composed of a 28-day screening, 2week run-in (fluticasone 200 1000 $\mu$ g daily or equivalent), and 52week treatment periods. Patients aged $\geq 16$ years $(\mathrm{N}=244)$ with persistent asthma for $\geq 6$ month before screening, FEV1 40-85\% predicted, and $>12 \%$ and $>200 \mathrm{ml}$ reversibility following albuterol inhalation started to receive twice-daily treatment with fluticasone/ formoterol $100 / 10 \mu \mathrm{g}, 250 / 10 \mu \mathrm{g}$ or $500 / 20 \mu \mathrm{g}$, based on the doses of ICS that had been used in a run-in period. Doses were allowed to increase or decrease according to the patients' symptoms, and treatment was continued for 52 weeks (Clinical Trials Gov JapicCTI number: 101341) [14]. As the phase III trials showed fluticasone/ formoterol pMDI had a good safety and efficacy profile in the two studies, fluticasone/formoterol pMDI has become available in Japan in November 2013.

To the best of our knowledge, there has been no report that investigated the effect of ADRB2 gene polymorphisms on response to regular use of fluticasone/formoterol pMDI. Therefore, in the phase III trials we've performed a prospective pilot study with patients whose ADRB2 genotypes had already been analyzed before the trials. This is the first prospective pilot study on effect of ADRB2 gene polymorphisms on response to regular use of fluticasone/formoterol pMDI.

\section{Materials and Methods}

\section{Patients and genotyping of ADRB2 polymorphism}

This study was performed with the approval of the Institutional Ethics Committee of Gunma Institute for Allergy and Asthma, Gunma, Japan and written informed consent was obtained from each participant before the study commenced. Diagnosis of bronchial asthma was confirmed using the GINA guidelines. All patients showed clinical symptoms that met the criteria for asthma, and they were diagnosed by experienced pulmonologists. Forced expiratory volume in one second (FEV1) was measured with a spirometer, and airway reversibility was defined as a $>12 \%$ and $>200 \mathrm{ml}$ increase in volume in the first second of forced expiration from baseline after inhalation of short-acting $\beta 2$-adrenergic bronchodilators. Smoking habit was ascertained by means of a questionnaire, and subjects with a smoking history that was either recent 12 months or equivalent to $\geq 10$ packyears were excluded.

DNA in the specimens obtained by rubbing buccal mucosa with a cotton swab from the patients was extracted by using QIAamp 96 DNA blood kits (Qiagen, Hilden, Germany). The target DNA sequence of the ADRB2 gene NM_000024.4 was amplified using a set of primers that were previously described [15,16] (forward, nucleotides 188-212: 5'-AGCCAGTGCGCTCACCTGCCAGACT-3'; reverse, nucleotides 406-383:5'-GCTCGAACTTGGCAATGGCTGTGA-3') to generate an ampliconof $219 \mathrm{bp}$ in length. Allelic discrimination assay for single nucleotide polymorphisms (SNPs) relating to the ADRB2 expression (rs 1042713) was carried out by using previously described
SNPs detective system, sequence-specific thermal-elution chromatography as reported from our laboratory $[17,18]$.

Because the number of patients who could participate in the trials was limited for each institution, nine patients (four in study I, and five in study II, respectively), whose ADRB2 genotypes had already been analyzed at our laboratory, were allowed to be involved in the present study (Table 1). Namely, one patient with wild-type ArgArg and three with variant-type ArgGly in study I, and one with wild-type ArgArg and four with variant-type ArgGly/GlyGly in study II respectively, participated in the phase III study conducted in Japan.

\section{Efficacy evaluations}

The primary outcome variables of the phase III trials conducted in Japan were lung function values, which are recognized as useful indicators that correlate well with clinical outcomes in asthma. Morning predose FEV1 values determined by a spirometer were assessed at approximately the same time ( \pm 1 hour) at each study visit immediately before the administration of study medication. The value of peak expiratory flow (PEF) was assessed twice daily using a MiniWright PEF meter (Clement Clark, Harlow, UK). Daily diary-based measures of asthma control, including asthma symptom-free days, awaking-free nights, and rescue medication use of short-acting B2adrenergic agonist (albuterol pMDI $90 \mu \mathrm{g}$ /inhalation), were recorded by the patient. In study I, follow-up clinic visits were scheduled 4 and 8 weeks after randomization. In study II, follow-up clinic visit were scheduled 4, 12, 28, 36 and 52 weeks after starting treatment. The primary endpoint was the changes of lung function tests (predose PEF and FEV1 values) at each study visit. The main secondary endpoints were changes in daily diary-based measures of asthma control mentioned above. The baseline values of PEF were defined as the mean value for the last 10 days of the run-in period, excluding the day of randomization, and that at each week were the mean value for the last 28 days. A symptom-free day was defined as a 24 -hour period during which a patient did not experience any asthma symptoms, and a rescue medication-free day was defined as a 24 -hour period during which a patient did not use rescue medication.

\section{Statistical analysis}

The data of each lung function value of the patients were collected at each visit in the phase III trials. Statistical analysis for the changes from baseline (week 0) to each subsequent visit for lung function values, PEF and FEV1, was analyzed using a paired t-test. A p-value of $<0.05$ was considered statistically significant.

\section{Results}

Figure 1 shows the changes of predose PEF and FEV1 values of the patients in study I (8-week, multicenter randomized single-blinded parallel-group study). Morning and evening PEF values at baseline (week 0) were $368.5 \pm 38.1$ (mean $\pm \mathrm{SEM}$ ) and $369.5 \pm 39.8 \mathrm{~L} / \mathrm{min}$, respectively. Morning and evening PEF values at the end of the 8-week treatment were $376.9 \pm 39.8$ and $382.2 \pm 40.1 \mathrm{~L} / \mathrm{min}$, and the increase of morning and evening PEF values were significant $(p=0.041$ in morning PEF and $\mathrm{p}=0.032$ in evening $\mathrm{PEF}$, respectively) (Figure $1 \mathrm{~A}$ and Figure 1B). On the other hand, no significant change of FEV1 was observed (Figure 1C). Daily diary-based measures of asthma control, including asthma symptom-free days, awaking-free nights, and rescue medication use of the patients in study I are presented in Table 2. 
Citation: Motohiro Kurosawa, Tatsuo Yukawa and Eijin Sutoh (2015) A Pilot Study on Effect of Beta2-Adrenergic Receptor Gene Polymorphism on Response to Fluticasone/Formoterol Inhaler in Patients with Persistent Asthma. J Allergy Ther 6: 208. doi: $10.4172 / 2155-6121.1000208$

Page 3 of 6

\begin{tabular}{|c|c|c|c|c|}
\hline Name (initial) & Age (years) & Gender & Genotype & Daily Dose ${ }^{a}$ \\
\hline \multicolumn{5}{|c|}{ In 8-week, multicenter randomized single-blinded parallel group study } \\
\hline YM & 28 & female & ArgArg & Unknown ${ }^{b}$ \\
\hline sw & 58 & female & ArgGly & Unknown ${ }^{\mathrm{b}}$ \\
\hline MT & 41 & female & ArgGly & Unknown ${ }^{b}$ \\
\hline HK & 56 & male & ArgGly & Unknown ${ }^{b}$ \\
\hline \multicolumn{5}{|c|}{ In a long-term (52 weeks), multicenter open-label study } \\
\hline $\mathrm{SN}$ & 56 & male & ArgArg & $1000 / 40 \mu g$ \\
\hline HT & 48 & female & GlyGly & $1000 / 40 \mu g$ \\
\hline TK & 42 & female & GlyGly & $1000 / 40 \mu \mathrm{g}$ \\
\hline NT & 42 & female & GlyGly & $200 / 20 \mu \mathrm{g}$ and $500 / 20 \mu \mathrm{g}$ since 28 week \\
\hline $\mathrm{EH}$ & 48 & female & ArgGly & $500 / 20 \mu \mathrm{g}$ and $1000 / 40 \mu \mathrm{g}$ since 28 week \\
\hline
\end{tabular}

Table 1: ADRB2 genotype of nine patients in this study, which was performed in fluticasone/formoterol pressurized meter-dose inhaler phase III trials in Japan (8-week, multicenter randomized single-blinded parallel group study, and 52-week, multicenter open-label study).

\begin{tabular}{|c|c|c|c|c|c|}
\hline & \multirow[b]{2}{*}{ Patient name } & \multirow{2}{*}{$\begin{array}{l}\text { Symptom-free days } \\
(\%)\end{array}$} & \multirow{2}{*}{$\begin{array}{l}\text { Awakening-free nights } \\
\text { (\%) }\end{array}$} & \multicolumn{2}{|c|}{ Rescue medication use } \\
\hline & & & & Days (\%) & Inhalation/day \\
\hline & \multicolumn{5}{|l|}{ YM } \\
\hline Baseline & & 20 & 100 & 20 & 0.2 \\
\hline \multirow[t]{2}{*}{8 week } & & 73.2 & 100 & 1.8 & 0 \\
\hline & \multicolumn{5}{|l|}{ sw } \\
\hline Baseline & & 0 & 100 & 90 & 2.1 \\
\hline \multirow[t]{2}{*}{8 week } & & 0 & 100 & 46.4 & 1.1 \\
\hline & \multicolumn{5}{|l|}{ MT } \\
\hline Baseline & & 90 & 100 & 10 & 0.2 \\
\hline \multirow[t]{2}{*}{8 week } & & 94.6 & 100 & 5.4 & 0.1 \\
\hline & \multicolumn{5}{|l|}{ HK } \\
\hline Baseline & & 0 & 100 & 30 & 0.3 \\
\hline 8 week & & 0 & 100 & 47.2 & 0.8 \\
\hline
\end{tabular}

Table 2: Changes in daily diary-based measures of asthma control of patients in 8-week, multicentre randomized single-blinded parallel group study.

After study I in the phase III study was completed, the key was opened showing that patients YM, MT and HK were controlled with twice-daily inhalation of fluticasone/formoterol $100 / 10 \mu \mathrm{g}$, and patient SW was twice-daily inhalation of fluticasone $100 \mu \mathrm{g}$. Morning and evening PEF values of patient SW at baseline (week 0) and 8 week were 343.0, 346.5 L/min in morning PEF, and 340.0, 345.0 L/min in evening
PEF, respectively. The ADRB2 genotype of the patients treated with twice-daily use of fluticasone/formoterol 100/10 $\mu \mathrm{g}$ was either ArgArg or ArgGly genotype. Increase of symptom-free days and decrease of rescue medication use was observed in patient YM with ArgArg homozygote of the ADRB2 gene. 
Citation: Motohiro Kurosawa, Tatsuo Yukawa and Eijin Sutoh (2015) A Pilot Study on Effect of Beta2-Adrenergic Receptor Gene Polymorphism on Response to Fluticasone/Formoterol Inhaler in Patients with Persistent Asthma. J Allergy Ther 6: 208. doi: $10.4172 / 2155-6121.1000208$

Page 4 of 6

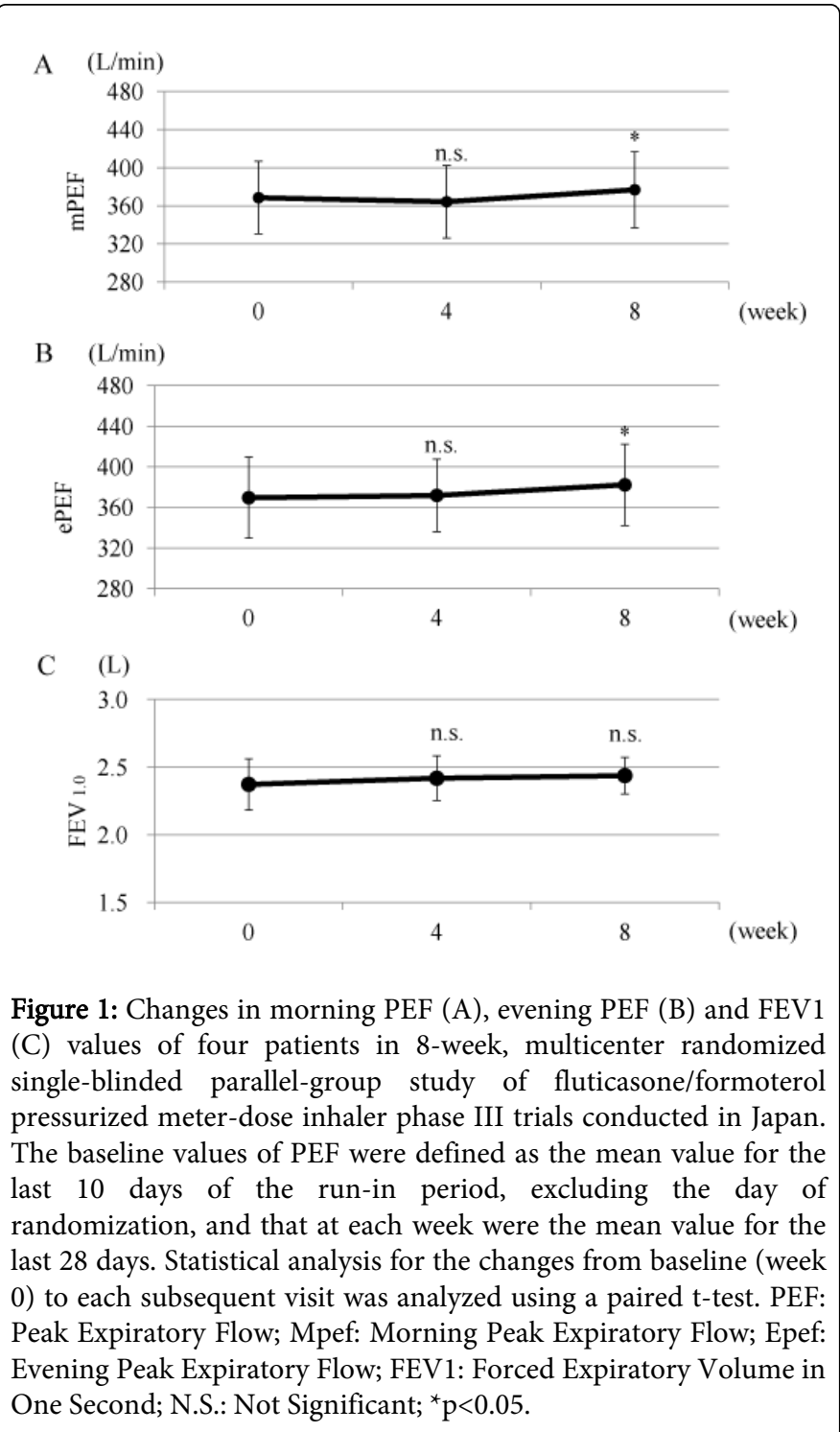

Figure 2 shows the changes of predose PEF and FEV1 values of the patients in study II (52-week, multicenter open-label study). The morning PEF values at baseline (week 0) and that at 36 week were $271.4 \pm 26.8$ and $302.8 \pm 23.6 \mathrm{~L} / \mathrm{min}$, respectively. A significant increase of morning PEF values from baseline with 36-week treatment was observed $(\mathrm{p}=0.018)$ (Figure $2 \mathrm{~A})$. The evening $\mathrm{PEF}$ values at baseline, 36 week and 52 week were $288.8 \pm 36.0,321.8 \pm 28.7$ and $325.6 \pm 31.0 \mathrm{~L} / \mathrm{min}$, respectively. A significant increase of evening PEF values from baseline with 36 -week and 52-week treatment was observed ( $\mathrm{p}=0.031$ and 0.014 , respectively) (Figure $2 \mathrm{~B}$ ). The FEV1 values at baseline and 36 week were $1.504 \pm 0.139$ and $1.668 \pm 0.119 \mathrm{~L}$, respectively. The change of FEV1 values from baseline with 36 -week treatment was significant $(\mathrm{p}=0.018)$ (Figure $2 \mathrm{C})$. The improvement of lung function tests (predose PEF and FEV1) from baseline with either 36- or/and 52-week treatment was present in the patients irrespective of their genotype of ADRB2 gene. Daily diary-based measures of asthma control, including asthma symptom-free days, awaking-free nights, and rescue medication use of five patients in study II are shown in Table 3. All of the daily diary-based measures of asthma control were improved from baseline in each patient over the treatment period.

\begin{tabular}{|c|c|c|c|c|}
\hline \multirow{2}{*}{ Patient name } & \multirow{2}{*}{$\begin{array}{c}\text { Symptom- } \\
\text { free days (\%) }\end{array}$} & \multirow{2}{*}{$\begin{array}{c}\text { Awakening- } \\
\text { free nights } \\
(\%)\end{array}$} & \multicolumn{2}{|c|}{ Rescue medication use } \\
\hline & & & Days (\%) & Inhalation/day \\
\hline \multicolumn{5}{|l|}{ SN } \\
\hline Baseline & 0 & 0 & 60 & 0.7 \\
\hline 36 week & 0 & 0 & 0 & 0 \\
\hline 52 week & 0 & 0 & 0 & 0 \\
\hline \multicolumn{5}{|l|}{ HT } \\
\hline Baseline & 60 & 80 & 40 & 0.4 \\
\hline 36 week & 100 & 100 & 0 & 0 \\
\hline 52 week & 96.4 & 100 & 3.6 & 0.1 \\
\hline \multicolumn{5}{|l|}{ TK } \\
\hline Baseline & 0 & 100 & 30 & 0.4 \\
\hline 36 week & 0 & 100 & 0 & 0 \\
\hline 52 week & 0 & 100 & 3.6 & 0 \\
\hline \multicolumn{5}{|l|}{ NT } \\
\hline Baseline & 10 & 100 & 30 & 0.3 \\
\hline 36 week & 85.7 & 100 & 0 & 0 \\
\hline 52 week & 76.2 & 90.5 & 0 & 0 \\
\hline \multicolumn{5}{|l|}{ EH } \\
\hline Baseline & 70 & 90 & 10 & 0.1 \\
\hline 36 week & 100 & 100 & 0 & 0 \\
\hline 52 week & 100 & 100 & 0 & 0 \\
\hline
\end{tabular}

Table 3: Changes in daily diary-based measures of asthma control of patients in a long-term (52 weeks), multicenter open-label study.

\section{Discussion}

To the best of our knowledge, there has been no report which investigated the effect of ADRB2 gene polymorphisms on response to regular use of fluticasone/formoterol pMDI. So, we conducted a prospective pilot study on effect of ADRB2 gene polymorphisms on response to regular use of fluticasone/formoterol pMDI in its phase III trials in Japan.

The most commonly cited SNPs in the ADRB2 gene occur at nucleotide position 46 (guanine/adenine) and 79 (cytosine/guanine), and result in the substitution of glycine (Gly) for Arg at codon 16 (Arg16Gly) and glutamic acid (Glu) for glutamine (Gln) at codon 27 (Gln27Glu), respectively. Following the identification of SNPs in the ADRB2 gene that affect cell-surface expression or ligand-binding activity of the receptor, there has been particular interest in pharmacogenetic associations related to this receptor [19-22]. In two 
Citation: Motohiro Kurosawa, Tatsuo Yukawa and Eijin Sutoh (2015) A Pilot Study on Effect of Beta2-Adrenergic Receptor Gene Polymorphism on Response to Fluticasone/Formoterol Inhaler in Patients with Persistent Asthma. J Allergy Ther 6: 208. doi: $10.4172 / 2155-6121.1000208$

Page 5 of 6

common polymorphisms, Arg16Gly and Gln27Glu of the ADRB2 gene, only the Arg16Gly polymorphism was investigated in the present study because of very low frequency of minor allele of Gln27Glu polymorphism in Japanese [23].

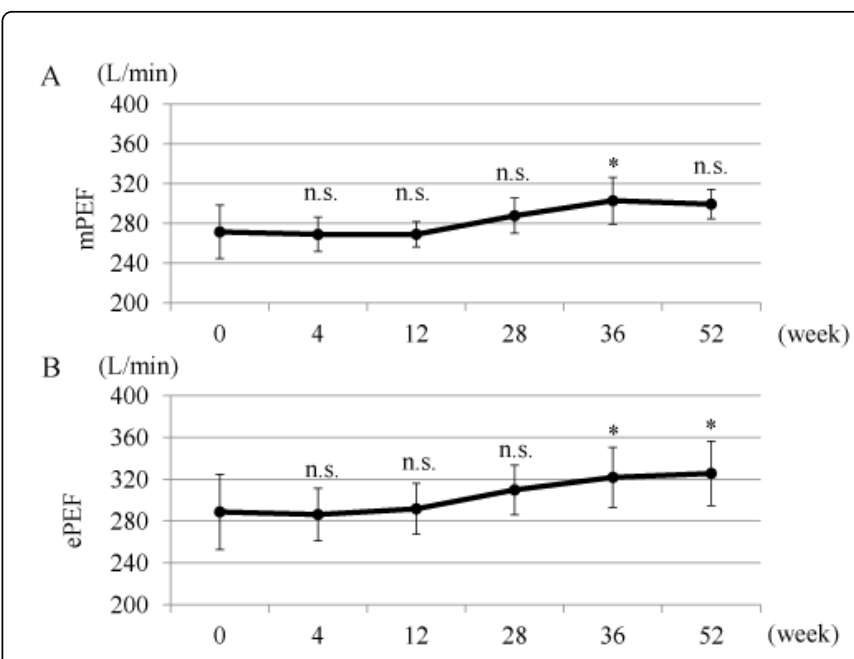

C (L)

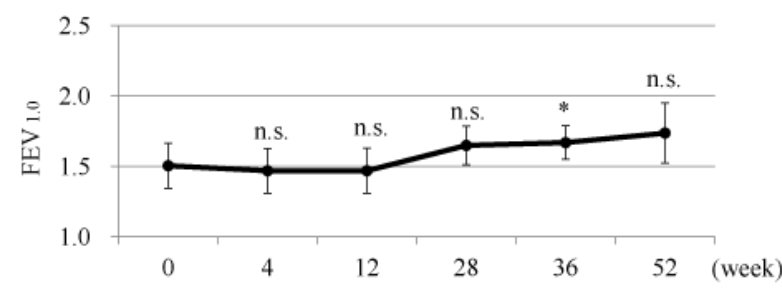

Figure 2: Changes in morning PEF (A), evening PEF (B) and FEV1 (C) values of five patients in a long-term (52 weeks), multicenter open-label study of fluticasone/formoterol pressurized meter-dose inhaler phase III trials conducted in Japan. The baseline values of PEF were defined as the mean value for the last 10 days of the runin period, excluding the day of randomization, and that at each week were the mean value for the last 28 days. Statistical analysis for the changes from baseline (week 0 ) to each subsequent visit was analyzed using a paired t-test. PEF: Peak Expiratory Flow; Mpef: Morning Peak Expiratory Flow; Epef: Evening Peak Expiratory Flow; FEV1: Forced Expiratory Volume in One Second; N.S.: Not Significant; ${ }^{*} \mathrm{p}<0.05$.

As the number of patients who were able to participate in the phase III trials was limited, nine patients were allowed to be involved in this study which investigated the effect of ADRB2 gene polymorphisms on lung function and asthma control to regular use of formoterol/ fluticasone pMDI. In 8-week, multicenter randomized single-blinded parallel-group study of the trials, the patients with either wild-type ArgArg or variant-type ArgGly were shown to be treated with fluticasone/formoterol pMDI, and the PEF values changed from baseline were increased at the end of the treatment. In 52-week, openlabel study of the trials, the improvement of lung function tests (PEF and FEV1) from baseline with the treatment was observed in all five patients, and the daily diary-based measures of asthma control were improved from baseline in each patient over the treatment period irrespective of their genotype of ADRB2.
Safety concerns have recently been raised regarding the regular use of fluticasone/salmeterol inhaler, and some studies suggested patients with asthma who are homozygous ArgArg at the 16th amino acid position of the ADRB2 gene benefit less from treatment with fluticasone/salmeterol than do those homozygous GlyGly [6,7]. In contrast with fluticasone/salmeterol, short- and long-term pharmacogenetic studies of budesonide/formoterol did not show an effect of Gly16Arg genotype on safety measures or clinical outcomes in response to budesonide/formoterol [24-26]. Possible explanation for the difference between these ICSs/LABAs involves the choice of LABA; formoterol versus salmeterol, because investigations about the effects of ADRB2 gene polymorphism on ex vivo and in vivo function of $\beta 2$-adrenoceptors in asthmatic patients suggested that ADRB2 gene polymorphism had no significant effect on response to formoterol [27]. Concerning about the differences related to using different ICSs, fluticasone versus budesonide in fluticasone/formoterol and budesonide/formoterol inhalers may mean little clinically [28,29]. In fact, one randomized, double-blind, double-dummy, multicenter 12week phase III study demonstrated comparable efficacy of fluticasone/ formoterol to budesonide/formoterol [28], and the other 12-week, open-label multicenter phase III trial reported fluticasone/formoterol inhaler showed non-inferiority to budesonide/formoterol formulation [29].

In conclusion, this prospective pilot study might suggest inheritance of ADRB2 gene polymorphisms may not appear to effect clinical outcomes with fluticasone/formoterol pMDI. Further investigations are needed to replicate this observation using a large size of study population and confirm pharmaco-ethnic differences.

\section{References}

1. Global Initiative for Asthma (GINA), National Heart, Lung and Blood Institute (NHLBI) Bethesda (MD) (2006) Global Strategy for Asthma Management and Prevention.

2. Chowdhury BA, Dal Pan G (2010) The FDA and safe use of long-acting beta-agonists in the treatment of asthma. N Engl J Med 362: 1169-1171.

3. Chowdhury BA, Seymour SM, Levenson MS (2011) Assessing the safety of adding LABAs to inhaled corticosteroids for treating asthma. $\mathrm{N}$ Engl J Med 364: 2473-2475.

4. Israel E, Drazen JM, Liggett SB, Boushey HA, Cherniack RM, et al. (2000) The effect of polymorphisms of the beta(2)-adrenergic receptor on the response to regular use of albuterol in asthma. Am J Respir Crit Care Med 162: 75-80.

5. Israel E, Chinchilli VM, Ford JG, Boushey HA, Cherniack RM, et al. (2004) Use of regularly scheduled albuterol treatment in asthma: Genotype-stratified, randomized, placebo-controlled cross-over trial. Lancet 364: 1505-1512.

6. Wechsler ME, Lehman E, Lazarus SC, Lemanske RF Jr, Boushey HA, et al. (2006) Beta-Adrenergic receptor polymorphisms and response to salmeterol. Am J Respir Crit Care Med 173: 519-526.

7. Palmer CN, Lipworth BJ, Lee S, Ismail T, Macgregor DF, et al. (2006) Arginine-16 beta2 adrenoceptor genotype predisposes to exacerbations in young asthmatics taking regular salmeterol. Thorax 61: 940-944.

8. Nelson HS, Weiss ST, Bleecker ER, Yancey SW, Dorinsky PM; SMART Study Group (2006) The Salmeterol Multicenter Asthma Research Trial: a comparison of usual pharmacotherapy for asthma or usual pharmacotherapy plus salmeterol. Chest 129: 15-26.

9. Wechsler ME, Kunselman SJ, Chinchilli VM, Bleeker E, Boushey HA, et al. (2009) Effect of $ß 2$-adrenergic receptor polymrophism on response to longacting $B 2$ agonist in asthma (LARGE trial): a genotype-stratified, randomized, placebo-controlled, crossover trial. Lancet 374: 1754-1764. 
Citation: Motohiro Kurosawa, Tatsuo Yukawa and Eijin Sutoh (2015) A Pilot Study on Effect of Beta2-Adrenergic Receptor Gene Polymorphism on Response to Fluticasone/Formoterol Inhaler in Patients with Persistent Asthma. J Allergy Ther 6: 208. doi: $10.4172 / 2155-6121.1000208$

Page 6 of 6

10. Bleecker ER, Nelson HS, Kraft M, Corren J, Meyers DA, et al. (2010) Beta2-receptor polymorphisms in patients receiving salmeterol with or without fluticasone propionate. Am J Respir Crit Care Med 181: 676-687.

11. Luijk B1, Kempsford RD, Wright AM, Zanen P, Lammers JW (2004) Duration of effect of single-dose inhaled fluticasone propionate on AMPinduced bronchoconstriction. Eur Respir J 23: 559-564.

12. Berger WE (2006) The use of inhaled formoterol in the treatment of asthma. Ann Allergy Asthma Immunol 97: 24-33.

13. Ohta K, Tohda Y, Adachi M (2013) Efficacy and safety of fluticasone/ formoterol pressurized metered-dose inhaler: randomized single-blinded parallel-group phase 3 study in Japanese adults with persistent asthma. Allergology Immunology 20: 1671-1685.

14. Tohda Y, Adachi M, Ohta K (2013) Efficacy and safety of fluticasone/ formoterol pressurized metered-dose inhaler: long-term safety and asthma control phase 3 study in Japanese adults with persistent asthma. Allergology Immunology 20: 1686-1704.

15. Dishy V1, Sofowora GG, Xie HG, Kim RB, Byrne DW, et al. (2001) The effect of common polymorphisms of the beta2-adrenergic receptor on agonist-mediated vascular desensitization. N Engl J Med 345: 1030-1035.

16. Sábato MF1, Irani AM, Bukaveckas BL, Schwartz LB, Wilkinson DS, et al. (2008) A simple and rapid genotyping assay for simultaneous detection of two ADRB2 allelic variants using fluorescence resonance energy transfer probes and melting curve analysis. J Mol Diagn 10: 258-264.

17. Kohyama K, Abe S, Kodaira K, Yukawa T, Hozawa S, et al. (2011) Arg16Gly $\beta 2$-adrenergic receptor gene polymorphism in Japanese patients with aspirin-exacerbated respiratory disease. Int Arch Allergy Immunol 156: 405-411.

18. Kurosawa M, Yukawa T, Hozawa S, Mochizuki H (2015) Recent advance in investigation of gene polymorphisms in Japanese patients with aspirinexacerbated respiratory disease. Allergol Immunopathol (Madr) 43: 92-100.

19. Reihsaus E, Innis M, MacIntyre N, Liggett SB (1993) Mutations in the gene encoding for the beta 2-adrenergic receptor in normal and asthmatic subjects. Am J Respir Cell Mol Biol 8: 334-339.

20. Green SA, Cole G, Jacinto M, Innis M, Liggett SB (1993) A polymorphism of the human beta 2-adrenergic receptor within the fourth transmembrane domain alters ligand binding and functional properties of the receptor. J Biol Chem 268: 23116-23121.

21. Green SA, Turki J, Innis M, Liggett SB (1994) Amino-terminal polymorphisms of the human ?2-adrenergic receptor impact distinct agonist-promoted regulatory properties. Biochemistry 33: 9414-9419.

22. McGraw DW, Forbes SL, Kramer LA, Liggett SB (1998) Polymorphisms of the $5^{\prime}$ leader cistron of the human beta2-adrenergic receptor regulate receptor expression. J Clin Invest 102: 1927-1932.

23. Munakata M, Harada Y, Ishida T, Saito J, Nagabukuro A, et al. (2006) Molecular-based haplotype analysis of the beta 2-adrenergic receptor gene (ADRB2) in Japanese asthmatic and non-asthmatic subjects. Allergol Int 55: 191-198.

24. Bleecker ER, Postma DS, Lawrance RM, Meyers DA, Ambrose HJ, et al. (2007) Effect of ADRB2 polymorphisms on response to longacting beta2agonist therapy: a pharmacogenetic analysis of two randomised studies. Lancet 370: 2118-2125.

25. Kim SH, Ye YM, Hur GY, Lee HY, Jee YK, et al. (2009) Effect of beta2adrenergic receptor polymorphism in asthma control of patients receiving combination treatment. Yonsei Med J 50: 182-188.

26. Berger WE, Noonan MJ (2010) Treatment of persistent asthma with Symbicort (budesonide/formoterol inhalation aerosol): an inhaled corticosteroid and long-acting beta2-adrenergic agonist in one pressurized metered-dose inhaler. J Asthma 47: 447-459.

27. Lipworth BJ, Hall IP, Tan S, Aziz I, Coutie W (1999) Effects of genetic polymorphism on ex vivo and in vivo function of beta2-adrenoceptors in asthmatic patients. Chest 115: 324-328.

28. Bodzenta-Lukaszyk A, Buhl R, Balint B, Lomax M, Spooner K, et al. (2012) Fluticasone/formoterol combination therapy versus budesonide/ formoterol for the treatment of asthma: a randomized, controlled, noninferiority trial of efficacy and safety. J Asthma 49: 1060-1070.

29. Antilla M, Castro F, Cruz Á, Rubin A, Rosário N, et al. (2014) Efficacy and safety of the single-capsule combination of fluticasone/formoterol in patients with persistent asthma: a non-inferiority trial. J Bras Pneumol 40: $599-608$. 